Gut, 1986, 27, 1338-1346

\title{
Changes in the gastric mucosa of the mouse associated with long lasting unsurmountable histamine $\mathrm{H}_{2}$ blockade
}

\author{
D POYNTER, S A M SELWAY, S A PAPWORTH, AND S R RICHES \\ From the Pathology Division, Glaxo Group Research, Ware, Hertfordshire
}

SUmmarY The oral administration of loxtidine to mice at doses of 600,250 , and $50 \mathrm{mg} / \mathrm{kg} / \mathrm{day}$ for 746 days produced carcinoid tumours of the gastric fundus. The fundic mucosa also showed marked atypical hyperplasia with changes in foveolar cells similar to those seen in early incomplete metaplasia. These effects may be related to the prolonged achlorhydria produced by this potent unsurmountable histamine $\mathrm{H}_{2}$ receptor antagonist.

Spontaneous tumours of the alimentary tract of mice are rare and most occur in the forestomach. ${ }^{1}$ Occasionally hyperplastic or neoplastic lesions of the glandular stomach are observed. ${ }^{2-5}$ Experimentally squamous cell carcinomas of the forestomach are produced $^{6} 7$ with $\mathrm{N}$-methyl-N'-nitro-N-nitrosoguanidine (MNNG) but surprisingly no tumours of the glandular stomach, such as occur in the rat, ${ }^{8}$ have been recorded. The mouse glandular stomach is susceptible, however, as whole body irradiation leads to precancerous polypoid hyperplasia and adenocarcinoma. ${ }^{9}$ Loxtidine is a potent, noncompetitive, unsurmountable histamine $\mathrm{H}_{2}$ antagonist. ${ }^{10}$ Its administration to rodents produces unremitting achlorhydria and in rats treated for prolonged periods the late development of carcinoid tumours of the fundus. ${ }^{11}$ The present communication describes the more extensive and different gastric changes seen in mice which were given loxtidine for 107 weeks, a major part of their normal life span.

\section{Methods}

ANIMALS

Loxtidine was administered daily in the drinking water to mice of the C57BL/10ScSn strain from the age of 6-8 weeks onwards. Treatment continued for 107 weeks. It was calculated that mean dose levels of 50,250 , and $600 \mathrm{mg} / \mathrm{kg} /$ day were attained. Precise plasma levels of loxtidine were measured by the

Address for correspondence: Dr D Poynter, Pathology Division, Glaxo Group Research, Ware, Herts. SG12 0DJ.

Received for publication 10 March 1986. method of Harrison et al. ${ }^{12}$ There were 55 male and 55 female mice in each treated group and 105 mice of each sex in the untreated control groups. The animals were inspected frequently for signs of illness and also palpated to detect swellings. Each mouse found dead, or killed was subjected to a careful post mortem examination. Mice were housed five to a cage and fed Mouse No. 1 expanded diet. ${ }^{*}$ The techniques used in this study were similar to those used in our previous study in the rat. ${ }^{11}$

\section{Results}

SURVIVAL

Treatment with loxtidine did not affect survival and after 107 weeks the percentage of each group can be seen in Table 1.

PLASMA CONCENTRATIONS OF LOXTIDINE Appreciable levels were always seen in the high dose group (3870-12047 $\mathrm{ng} / \mathrm{ml}$ ) and in the intermediate group $(821-2290 \mathrm{ng} / \mathrm{ml})$ but at the low level considerably less was found $(132-268 \mathrm{ng} / \mathrm{ml})$.

Table 1 Percentage of mice surviving at 107 weeks

\begin{tabular}{lll}
\hline & Male & Female \\
\hline Control & 41 & 39 \\
Low & 38 & 40 \\
Intermediate & 40 & 58 \\
High & 49 & 40 \\
\hline
\end{tabular}

*SQC Rat and Mouse Maintenance Diet No. 1 Expanded SDS. Witham, Essex. 
TUMOURS

With the exception of those found in the stomach, all were of the types commonly found in this strain of mouse and none had any relationship to treatment.

\section{STOMACH CHANGES}

The proliferative and neoplastic changes found in the fundus are summarised in Table 2. Few mice died during the first 600 days of the study and nothing untoward was seen in their stomachs on macroscopic examination. On day 611 two treated mice died and both showed some slight nodular thickening of the fundic mucosa. No changes were noted in the squamous or pyloric regions. Thereafter, a large proportion of mice treated at the high and intermediate dose levels and dying between days 611 and the termination of the study showed obvious thickening and nodularity of the grossly enlarged fundic mucosa (Fig. 1).

Histological examination revealed a sequence of changes from minimal mucosal proliferation to marked bizarre exuberant and extensive proliferation (Fig. 2). The earliest histological change, mucosal thickening, was seen in a male mouse, treated at the high level for 161 days.

Few mice died between days 161 and 590, by which time the mucosa was thrown into folds giving a polypoid appearance. Scattered dilated glands of variable size and distribution, often with cyst formation were seen (Fig. 2) but no ulcers were found.

In association with these changes there were obvious disturbances of the normal cellular patterns. The gastric pits were elongated often with irregular, tortuous contours and obvious branching (Fig. 3). The surface epithelium showed hyperplasia and a disorderly arrangement of cells. There were some mitotic figures and apopotic bodies were common.

Table 2 Proliferative and neoplastic changes in the fundus

\begin{tabular}{|c|c|c|c|c|c|c|c|c|}
\hline & \multicolumn{4}{|c|}{ Male mice } & \multicolumn{4}{|c|}{ Female mice } \\
\hline & $C$ & $L$ & $I$ & $H$ & $C$ & $L$ & $I$ & $H$ \\
\hline $\begin{array}{l}\text { Number of mice/ } \\
\text { group }\end{array}$ & 105 & 55 & 55 & 55 & 105 & 55 & 55 & 55 \\
\hline $\begin{array}{l}\text { Mild atypical } \\
\text { hyperplasia }\end{array}$ & () & 30 & 10 & 6 & 0 & 33 & 33 & 21 \\
\hline $\begin{array}{l}\text { Moderate atypical } \\
\text { hyperplasia }\end{array}$ & 0 & 15 & 13 & 11 & 0 & 6 & 11 & 19 \\
\hline $\begin{array}{l}\text { Atypical } \\
\text { hyperplasia }+ \\
\text { carcinoids }\end{array}$ & () & 0 & 17 & 32 & 0 & 0 & 4 & 7 \\
\hline Total affected & 0 & 45 & 40 & 49 & 0 & 39 & 48 & 47 \\
\hline
\end{tabular}

In addition some nuclei tended to be heaped up and to have variable staining affinity size and shape.

Evidence of a change in the quality of mucus was seen. In untreated mice neutral mucin predominated, acidic mucin being found only in the pyloric glands and in trace amounts at the mucosquamous junction. In the hyperplastic mucosa of the treated mice acidic mucin was found in the fundic region in quantities similar to neutral mucin. The acidic mucin was predominantly sialomucin of the $\mathrm{N}$-acylated variety but small amounts of sulphomucin were also found.

Electron microscopy showed that the normal, neutral mucin secreting, foveolar cells in control mice contained dense staining mucous granules concentrated into the apical region. None showed obvious microvilli although in some there was an odd protuberance (Fig. 4). This was in contrast with the foveolar cells containing acid mucin which had less dense mucous granules of variable size with no apical concentration. All these cells had a number of poorly developed, scattered and irregularly arranged microvilli (Fig. 5).

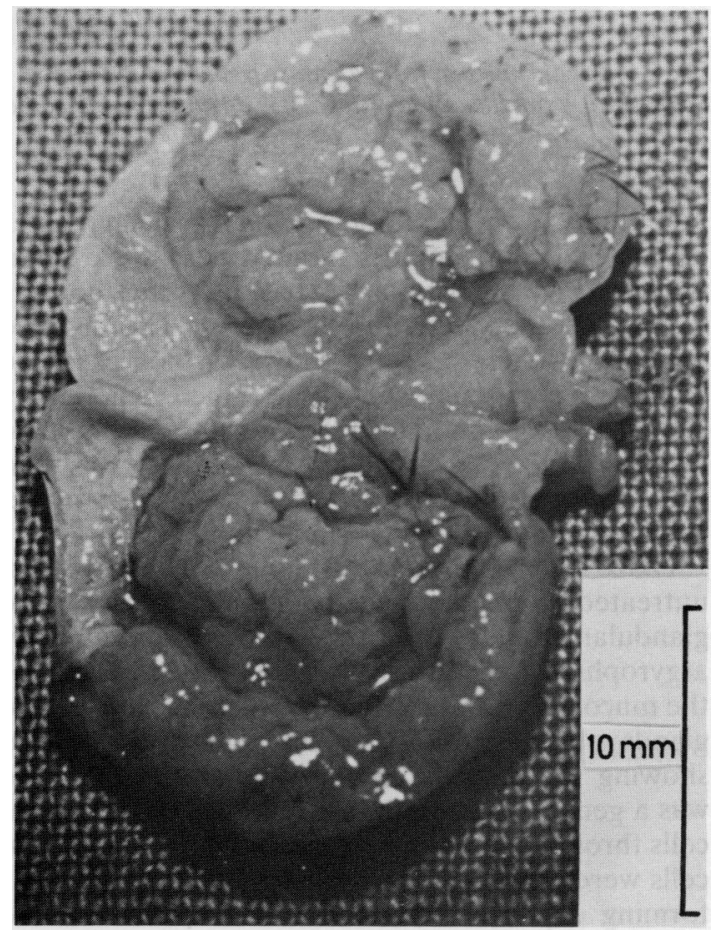

Fig. 1 Stomach from a mouse treated at $600 \mathrm{mg} / \mathrm{kg}$. Marked thickening and nodularity of the fundic mucosa are obvious. 


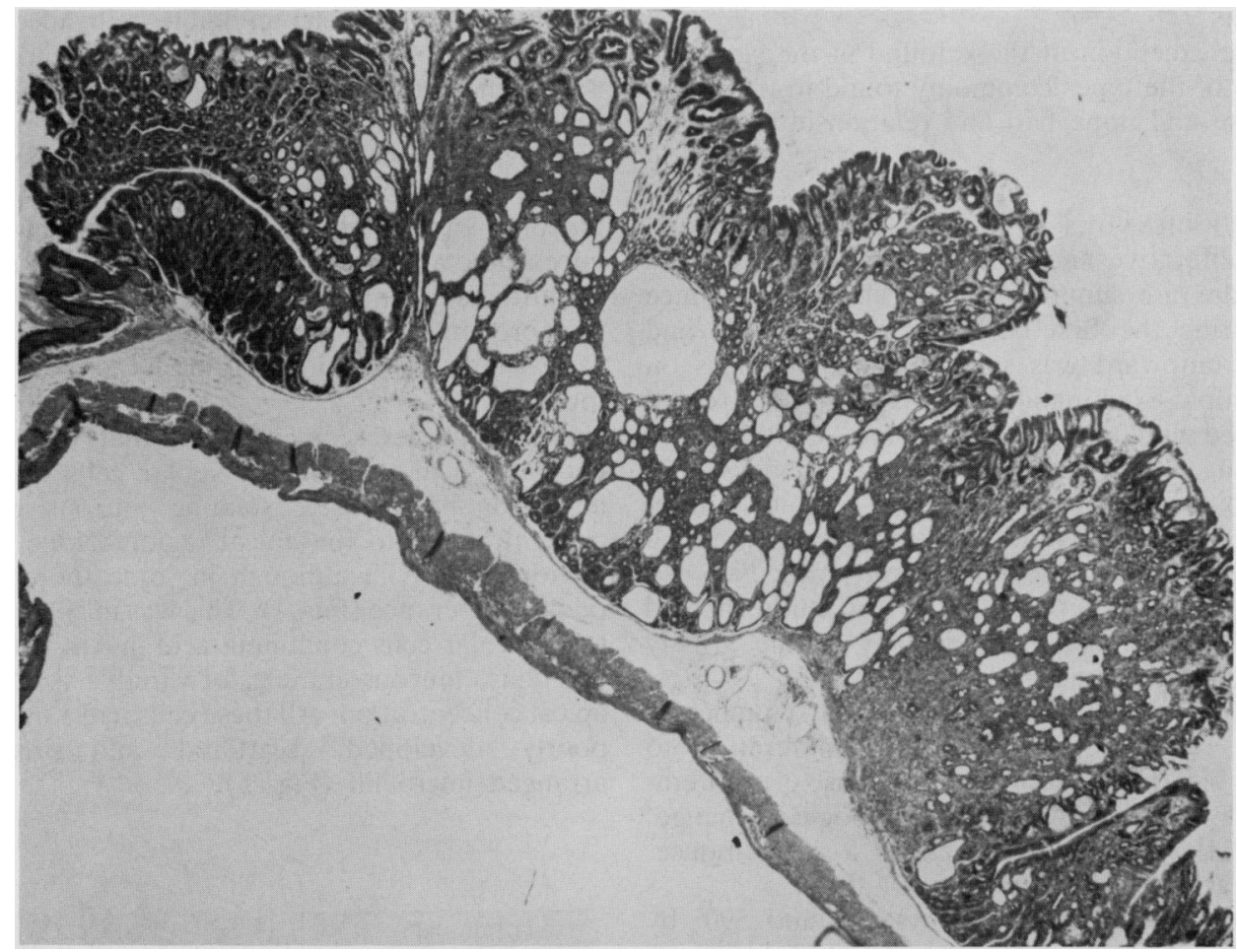

Fig. 2 Fundic mucosa from a mouse treated at $250 \mathrm{mg} / \mathrm{kg}$, for 744 days. There is marked polypoid hyperplasia and cystic dilatation. A small carcinoid deposit is distinguishable at the bottom right. Haematoxylin and eosin

Within the proliferating mucosa, focal aggregates of pale staining, undifferentiated cells were often present (Fig. 6). Such areas had indistinct borders but showed very few mitotic figures. The invasive potential of these cells was shown by their presence beneath the muscularis mucosae (Fig. 7) where they were seen as large nodular aggregates. In one case invasion of the muscle wall of the stomach was seen and in two cases malignant cells with large nuclei were found in draining lymph nodes (Fig. 8).

Diazo and Grimelius techniques showed that in untreated mice the neuroendocrine cells of the glandular fundic stomach were predominantly argyrophilic and were scattered in the lower half of the mucosa. Argentaffin cells occurred chiefly in the glands of the pylorus. In loxtidine treated mice showing proliferation of the fundic mucosa, there was a general increase in the numbers of argyrophil cells throughout the mucosa. The aggregates of pale cells were consistently argyrophilic as were the cells forming deposits beneath the muscularis mucosae and those found in the lymph nodes (Fig. 8).

Ultrastructural examination of the pale staining argyrophil cells demonstrated the presence of numerous small membrane bound neurosecretory granules in their cytoplasm. Most commonly the cells contained granules varying in diameter from 186 to $266 \mathrm{~nm}$ (Fig. 9). A few cells, however, contained granules typical of ECL cells, these being approximately $580 \mathrm{~nm}$ in diameter, with a dense core and wide electron lucent halo (Fig. 10). Finally, very few cells were seen which contained both small granules and granules typical of ECL cells. The neoplastic cells also showed prominent rough endoplasmic reticulum. Further confirmation of the neuroendocrine nature of the cells was provided by Dr J Rode who obtained positive results when using neurone-specific enolase as a marker. ${ }^{13}$

Tumour cells were consistently negative using specific antiserum techniques for secretory products. Good cross reactivity between the antisera and mouse tissue could be demonstrated by the strong positive staining of neuroendocrine cells of the pyloric mucosa in the case of antigastrin and antisomatostatin and by the positive staining of $\alpha$ cells in the pancreas in the case of anti-glucagon. Because no fresh tissue was available, techniques to 


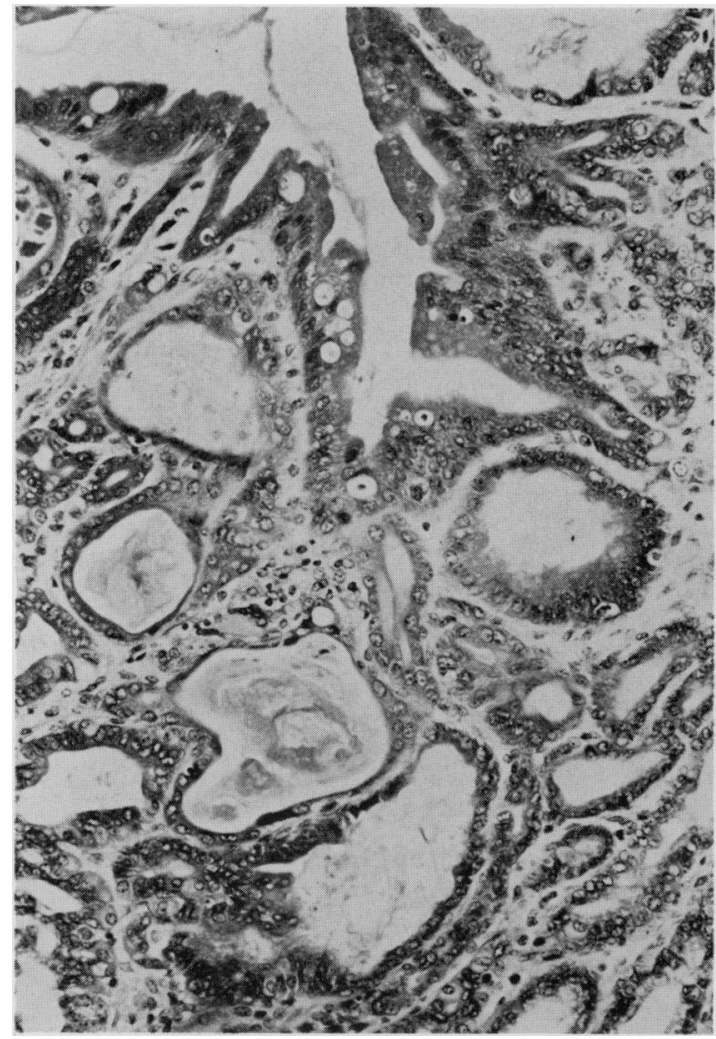

Fig. 3 Fundic mucosa from a mouse treated at $600 \mathrm{mg} / \mathrm{kg}$, for 633 days. There is hyperplasia of the surface epithelium, apoptosis and branching of glands. Haematoxylin and eosin.

show histamine and histidine decarboxylase were not used.

\section{Discussion}

Although loxtidine is not a genotoxic carcinogen ${ }^{11}$ mice treated for two years did develop marked proliferative changes in the fundic area of the stomach. These changes satisfy the criteria for 'atypical hyperplasia' ${ }^{14}$ In addition, many exhibited focal aggregates of argyrophilic cells which were positive for neurone-specific enolase and which, with electron microscopy, were found to contain typical neurosecretory granules. These characteristics denote the carcinoid nature of the aggregates. There was evidence of local invasion and in two cases metastatic deposits were found in lymph nodes. No specific functional activity could be ascribed to the tumours using specific antibody techniques.
No goblet cells were found in any stomach, even when using Alcian blue/PAS stained sections and no Paneth cells were ever recognised. Changes were, seen, however, in the type of mucus present in the foveolar cells and in their ultrastructure. These changes resembled those found in incomplete metaplasia of the human stomach where acidic mucins appear and where microvilli become more evident. ${ }^{1516}$ It is perhaps relevant to state that the distribution of mucin types in the mouse stomach closely resembles that seen in man. ${ }^{17}$

The gross proliferative changes seen in the majority of mice given loxtidine (Table 2) were not seen in rats, although this species did develop carcinoid tumours of the fundic stomach. ${ }^{11}$

Twice as many tumours were found in the high level group as in the intermediate group. The plasma concentrations in the high and intermediate groups, however, were much greater than those found at the low level where no carcinoid tumours were seen. In the rat unremitting achlorhydria was produced at all levels of treatment and no dose response was apparent. ${ }^{11}$

Omeprazole, an $\mathrm{H}^{+} \mathrm{K}^{+}$ATPase inhibitor, also effectively suppresses acid secretion for long periods. Treatment of rats led to fundic carcinoids but at 18 months mice only displayed 'hyperplastic gastrophy'. ${ }^{18}$ Unfortunately the study was terminated at this time so that the result of more prolonged treatment is unknown.

The difficulties of attempting to extrapolate results, such as those reported here for mice and those already published for rats, ${ }^{11}$ to the human clinical situation, have featured in a leading article in this journal in which the need to avoid prolonged excessive suppression was emphasised. ${ }^{19}$ In man an association between polypoidal carcinoid tumours of the stomach, hypergastrinaemia and achlorhydria is known, ${ }^{20}$ and it was suggested that, 'long term, uninterrupted achlorhydria produced by potent inhibitors of gastric acid secretion might therefore predispose to carcinoid tumours of the stomach'.

A continuous sequence from neuroendocrine cell hyperplasia through microcarcinoidosis is reported ${ }^{21}$ but not all the factors responsible for this are known. In the rat a relationship between prolonged hypergastrinaemia and ECL hyperplasia has been demonstrated ${ }^{22}$ but this may not explain how the process extends into malignancy. In a recent review $^{23}$ giving consideration to experimental rodent work and to clinical observations in man it was stated that, 'For reasons unknown, gastrinomas do not seem to give rise to ECLomas, despite the fact that gastrinomas cause ECL cell hyperplasia. Clearly, hypergastrinaemia is not the only, perhaps not even the most important, factor behind the 


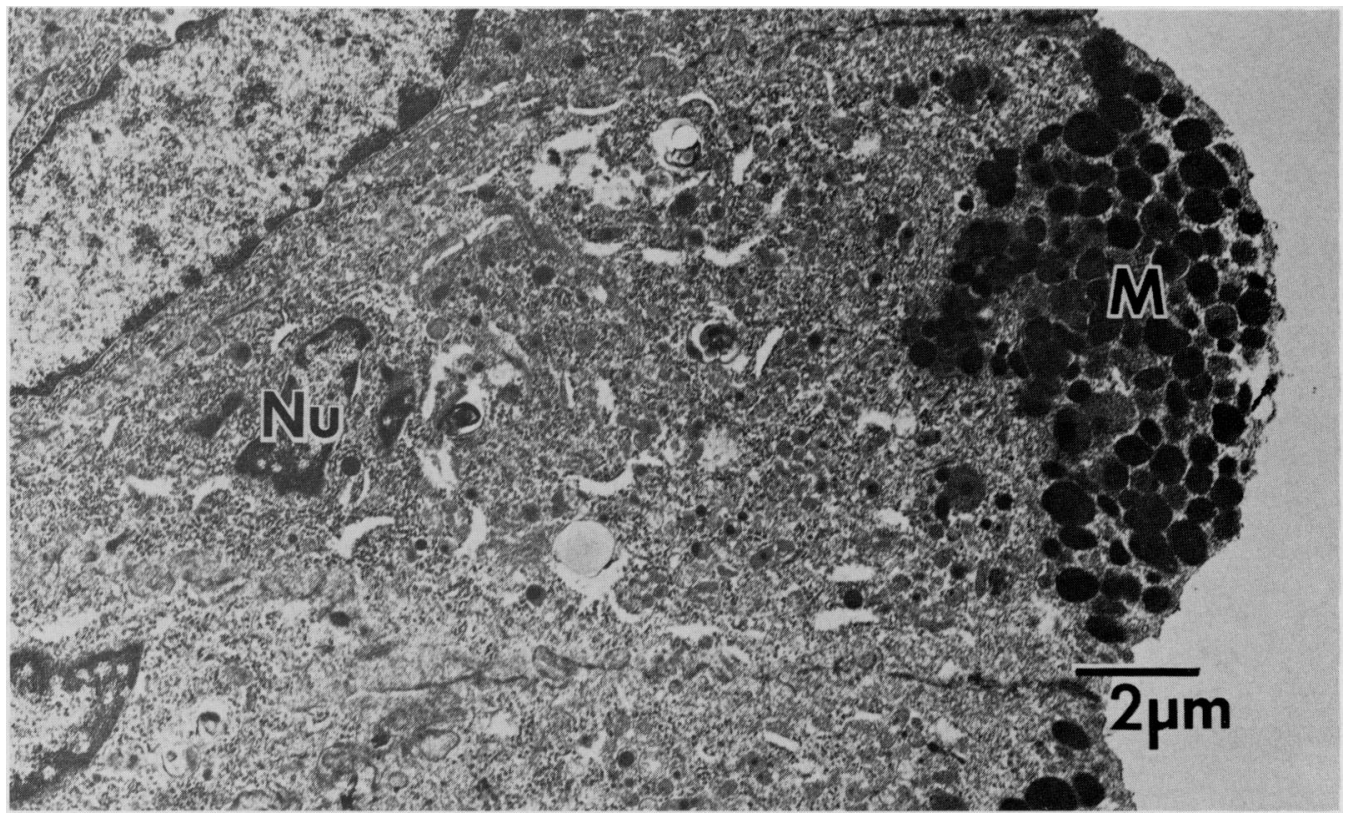

Fig. 4 Electron micrograph of a foveolar cell from an untreated control mouse. Abundant densely staining mucin granules (M) are present near the apex. The surface is smooth with the occasional small protuberance. (Nu=nucleus. (Formalin fixation).

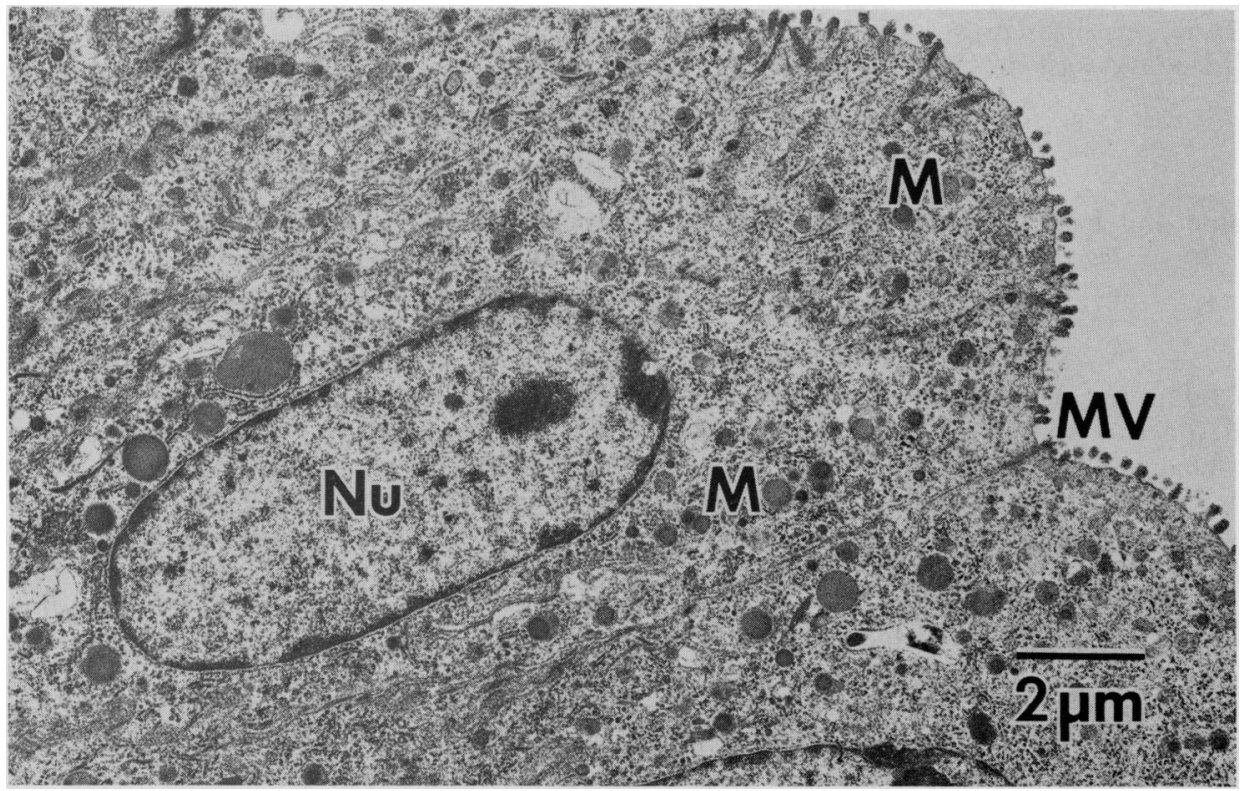

Fig. 5 Electron micrograph of a foveolar cell from a mouse treated at $600 \mathrm{mg} / \mathrm{kg}$. Mucin granules $(M)$, of varying staining affinity and size are scattered in the cell. There are a number of poorly developed microvilli $(M V)$. (Reprocessed from paraffin wax). 


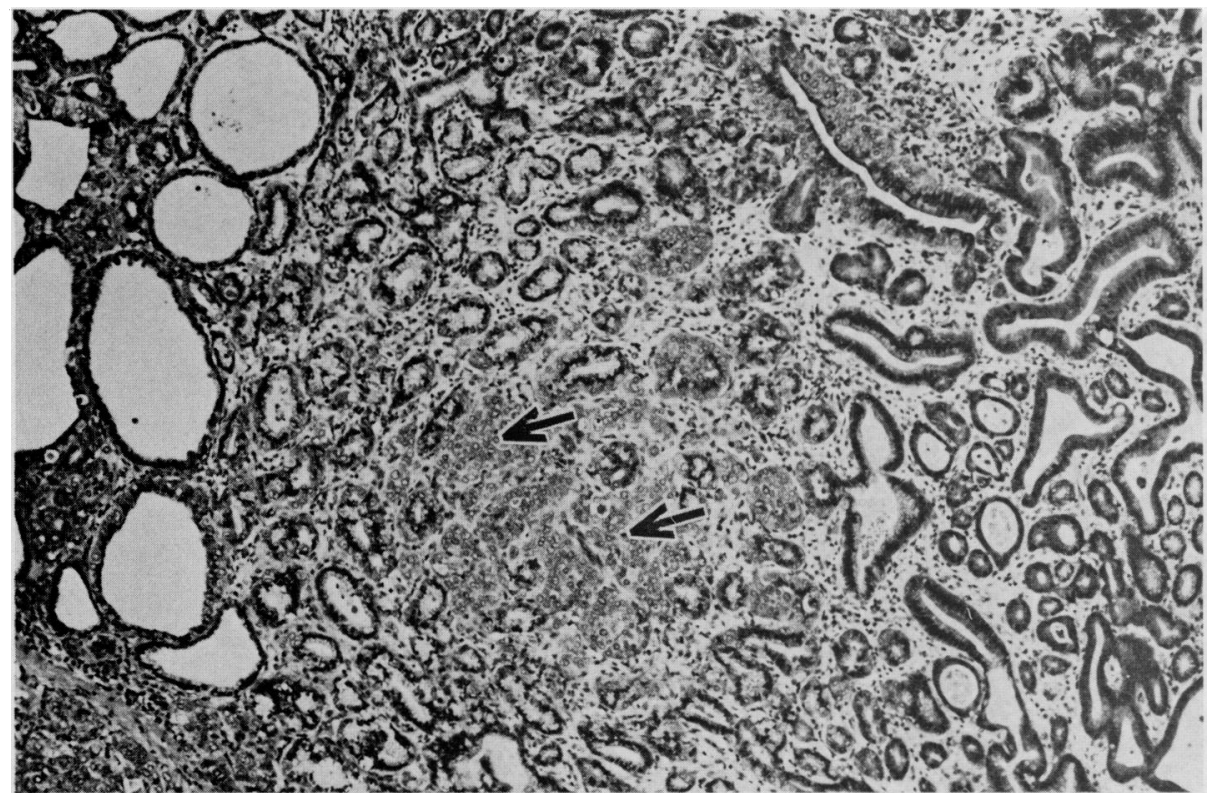

Fig. 6 Fundic mucosa of a mouse treated at $600 \mathrm{mg} / \mathrm{kg}$, for 746 days. There are aggregates of pale staining undifferentiated cells (arrows). Haematoxylin and eosin.

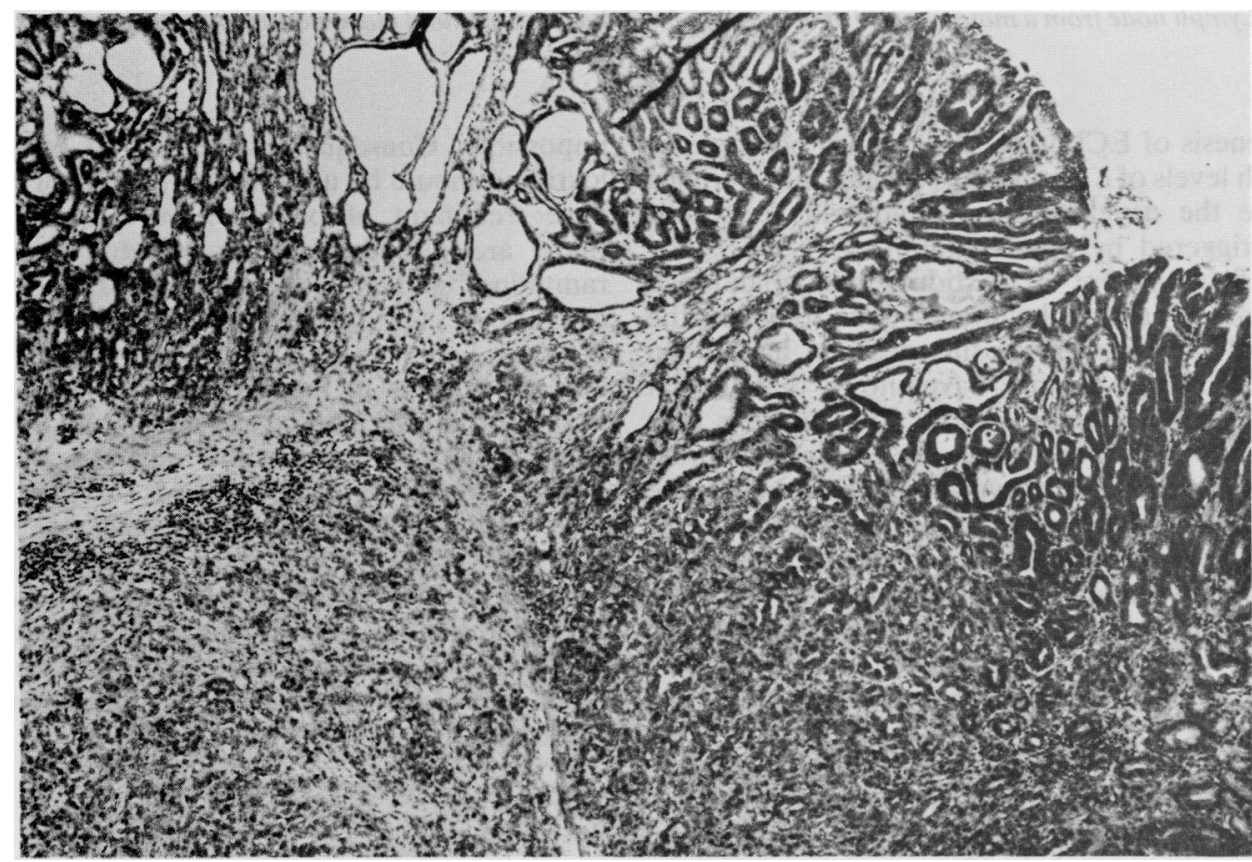

Fig. 7 Submucosal deposit of carcinoid cells in a mouse given $600 \mathrm{mg} / \mathrm{kg}$, for 746 days. Haematoxylin and eosin. 


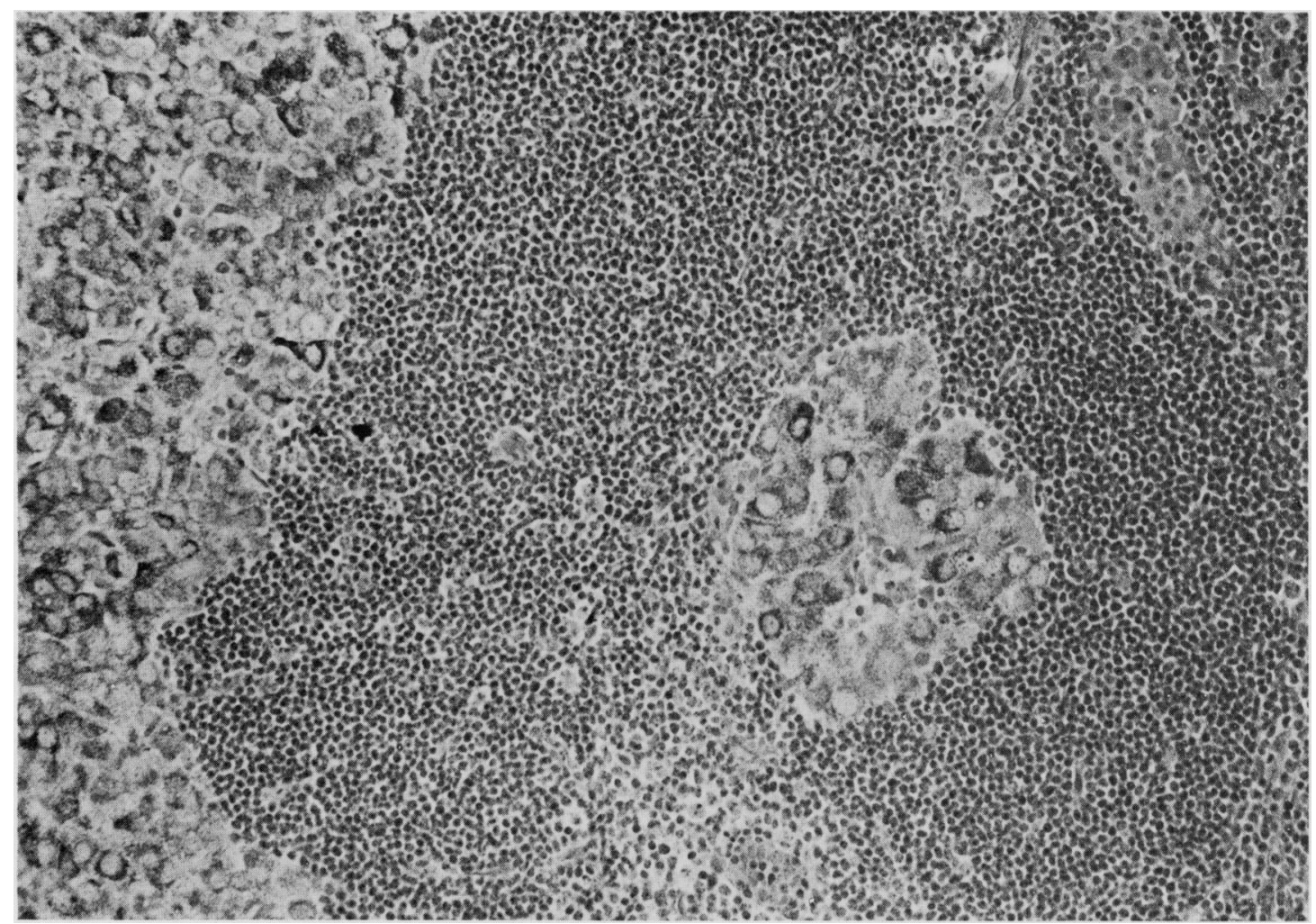

Fig. 8 Lymph node from a mouse treated at $600 \mathrm{mg} / \mathrm{kg}$, for 746 days. Carcinoid metastatic deposits are evident. Grimelius.

pathogenesis of ECLomas'. It was also pointed out that high levels of a circulating stimulus may perhaps facilitate the development of endocrine cell neoplasia triggered by other stimuli.

The development of loxtidine was abandoned when gastric carcinoid tumours were found in the rat $^{11}$ and the reasons for this decision have been given. ${ }^{24}$ Findings in mice have shown that the rat changes are not species specific. The mouse is very susceptible in that as well as developing carcinoid tumours, it shows an atypical hyperplasia of the fundic mucosa with some features suggestive of early incomplete metaplasia. Some of these changes may well be related to prolonged achlorhydria. The fact that there is, in man, a long postulated link between intestinal metaplasia and gastric carcinoma ${ }^{25}$ provides another reason for adopting a conservative approach.

The reason for performing long term studies in mice and rats is to seek any changes which may be indicative of a possible hazard in treated patients. The extrapolation and significance of these changes to man is, in our present state of knowledge, impossible. Consequently we do not believe that loxtidine should be used for the healing or maintenance treatment of peptic ulcer disease, because there are already effective treatments such as ranitidine $\mathrm{e}^{26}$ and cimetidine ${ }^{27}$ which produce no such changes.

We are grateful to the many people whose efforts ensured that this study was successfully completed. We freely acknowledge the unstinting help and advice from our colleagues $\mathrm{Dr} \mathrm{C}$ Pick, $\mathrm{Mr} \mathrm{R}$ Harcourt, Mr I Harman, Mrs P Fluck, Mr J Cooke, and $\mathrm{Mr} \mathrm{G}$ Ainge. We are indebted to $\operatorname{Dr} \mathrm{N} \mathrm{W}$ Spurling and $\mathrm{Mr} \mathrm{M}$ Tucker who arranged the in vivo part of the study and to Mrs Doreen Newton for preparing the manuscript. In particular we wish to thank Drs Basil Morson, Jeremy Jass, and Jurgen Rode for their valued opinions.

\section{References}

1 Rowlatt UF. Neoplasms of the alimentary canal of rats and mice. In: Cotchin E, Roe FTC, eds. Pathology of 


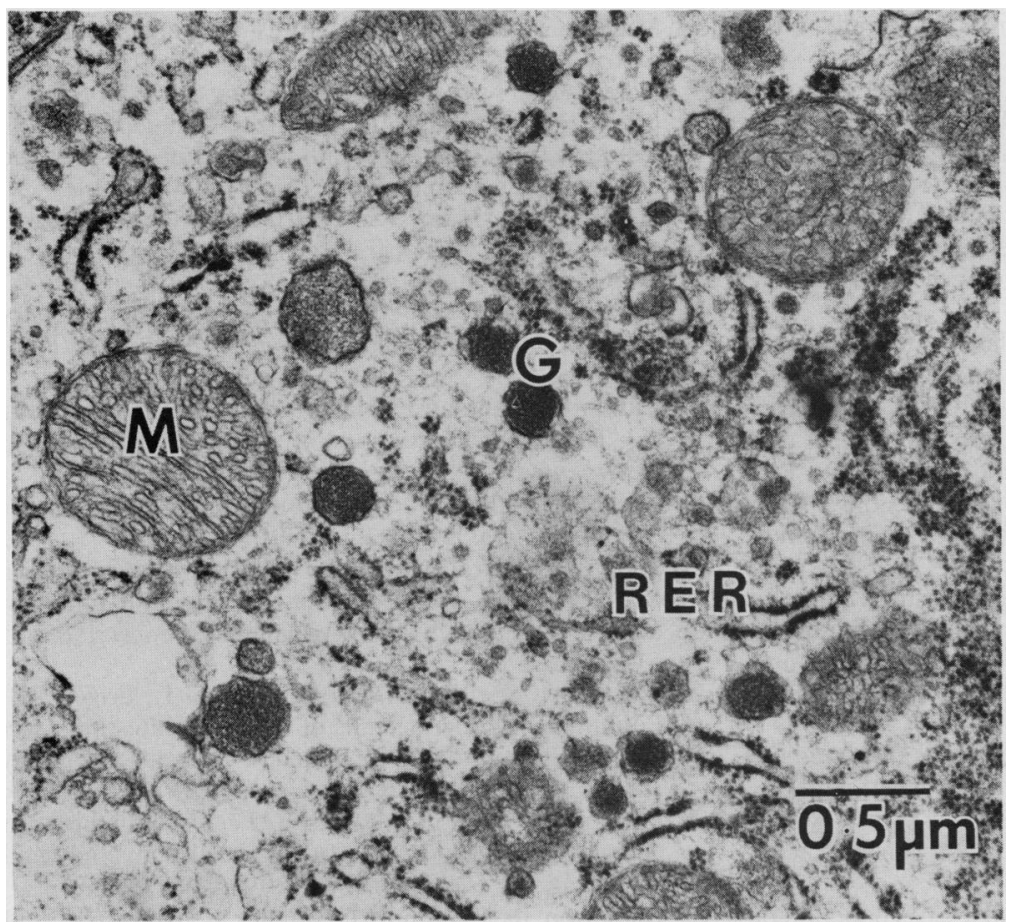

Fig. 9 Electron micrograph of tumour cells showing small round electron dense granules $(G)$. $M=$ mitochondria, $R E R=$ rough endoplasmic reticulum.

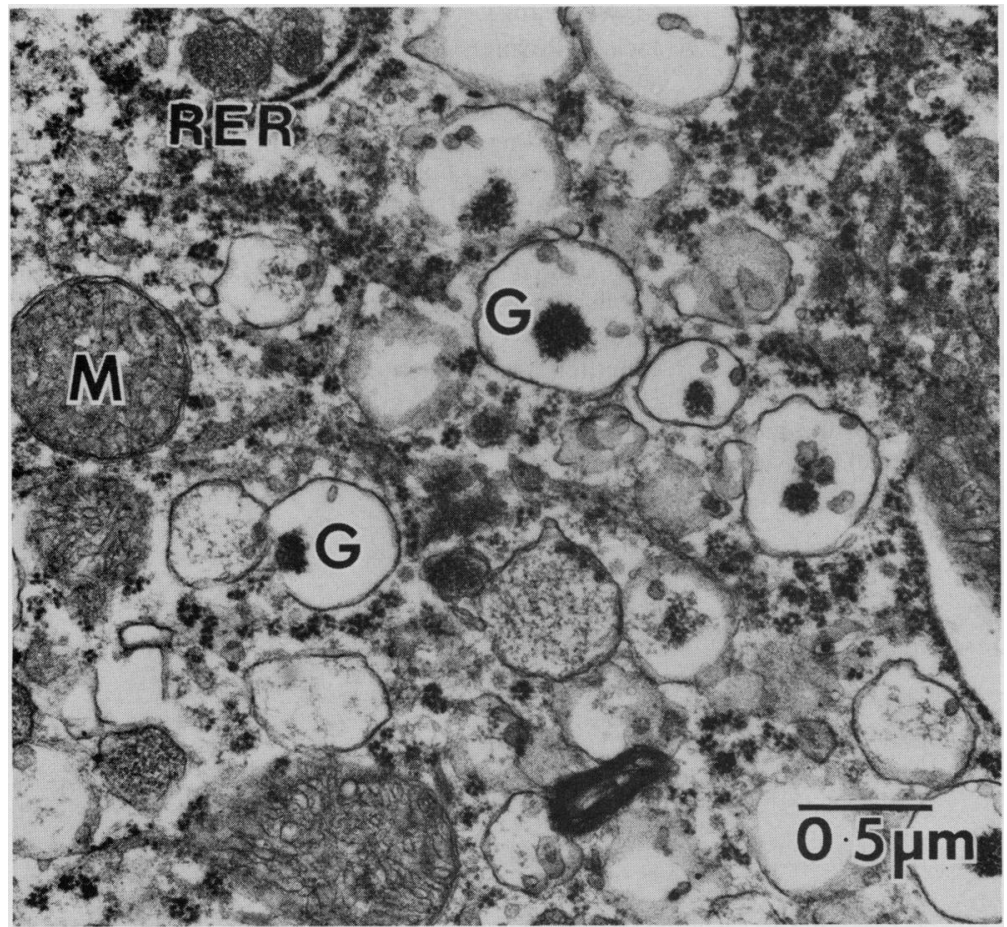

Fig. 10 Electron micrograph of tumour cell showing larger vesicular granules with electron dense cores, similar to $E C L$ granules $(G)$. $M=$ mitochondria, $R E R=$ rough endoplasmic reticulum. 
laboratory rats and mice. Oxford: Blackwell, 1967: 57-84.

2 Slye M, Holmes HF, Weel HG. Comparative pathology of cancer of the stomach with particular reference to the primary spontaneous malignant tumours of the alimentary canal in mice. J Cancer Res 1917; 2: 401-25.

3 Strong LC. Genetic analysis of induction of tumours by methylcholanthrene. IX. Induced and spontaneous adenocarcinomas of the stomach in mice. $J$ Natl Cancer Inst 1945; 5: 339-62.

4 Miller EW, Pybus FC. Hyperplastic and neoplastic lesions of the glandular stomach and intestine in two inbred strains of mice and their reciprocal hybrids. $\mathrm{Br} \mathrm{J}$ Cancer 1956; 10: 89-109.

5 Rowlatt C, Franks LM, Sheriff MU, Chesterman FC. Naturally occurring tumours and other lesions of the digestive tract in untreated C57BL mice. $J$ Natl Cancer Inst 1969; 43: 1353-68.

6 Schoental R, Bensted JPM. Gastro-intestinal tumours in rats and mice following various routes of administration of $\mathrm{N}$-methyl-N. Nitroso- $\mathrm{N}^{\prime}$-Nitroguanidine and N-Ethyl-N-Nitroso-N'-Nitroguanidine. $\mathrm{Br} J$ Cancer 1969; 23: 757-64.

7 Suzuki K, Yamamoto T. 1972. Personal Communication quoted in: Experimental Stomach Cancer. Methods in Cancer Res 1973; 7: 245-308.

8 Sugimura T, Kawachi T. Experimental stomach cancer. Methods Cancer Res 1973; 7: 245-308.

9 Upton AC, Cosgrove GE, Lushbaugh CC. Induction of carcinoma of the glandular stomach in mice by wholebody irradiation. GANN Monograph 1969; 8.

10 Brittain RT, Jack D, Reeves JJ, Stables R. Pharmacological basis for the induction of gastric carcinoid tumours in the rat by loxtidine an unsurmountable histamine $\mathrm{H}_{2}$-receptor blocking drug. $\mathrm{Br} \mathrm{J}$ Pharmacol 1985; 85: 843-7.

11 Poynter D, Pick CR, Harcourt RA et al. Association of long lasting unsurmountable histamine $\mathbf{H}_{2}$ blockade and gastric carcinoid tumours in the rat. Gut 1985; 26: 1284-95.

12 Harrison C, Jenner WN, Martin LE, Young SN. Radioimmunoassay of loxtidine and ranitidine in biological fluids. Biochem Soc Trans 1983; 11: 713-4.

13 Bishop AE, Polak JM, Facer P, Ferri G-L, Marangos PJ, Pearse AGE. Neuron-specific enolase - a common marker for endocrine cells and innervation of the gut and pancreas. Gastroenterology 1982; 83: 902-15.
14 Ming SC. Pathological features and significance of gastric dysplasia. In: Si-Chun Ming, ed. Precursors of gastric cancer. New York: Praegar, 1984.

15 Ming SC, Goldman H. Intestinal metaplasia and histogenesis of carcinoma in human stomach. Light and electron microscopic study. Cancer 1967; 9: 1418-29.

16 Goldman H, Ming SC. Fine structure of intestinal metaplasia and adenocarcinoma of the human stomach. Lab Invest 1968; 18: 203-10.

17 Sheahan DG, Jervis HR. Comparative histochemistry of gastrointestinal mucosubstances. Am J Anat 1976; 146: 103-32.

18 Ekman L, Hansson E, Havu N, Carlsson E, Lundberg C. Toxicological studies on omeprazole. Scand $J$ Gastroenterol 1985; 20; suppl 108: 53-69.

19 Elder J. Leading article: inhibition of acid and gastric carcinoids. Gut 1985; 26: 1279-83.

20 Harvey RF, Bradshaw MJ, Davidson CM, Wilkinson SP, Davies PS. Multifocal gastric carcinoid tumours, achlorhydria and hypergastrinaemia. Lancet 1985; 1: 51-4.

21 Solcia E, Capella C, Buffa R, Usellini L, Frigerio B, Fontana P. Endocrine cells of the gastrointestinal tract and related tumours. In: Ioachim HL, ed. Pathology Annual. New York: Raven Press, 1979: 9: 163-204.

22 Larsson $\mathrm{H}$, Carlsson $\mathrm{E}$, Mattson $\mathrm{H}$ et al. Plasma gastrin and gastric enterochromaffin like cell activation and proliferation. Gastroenterology 1986; 90: 391-9.

23 Hakanson R, Ekelund M, Sundler F. Activation and proliferation of gastric endocrine cells. In: Falkner S, Hakanson R, Sundler F. eds. Evolution and tumour pathology of the neuroendocrine system. Amsterdam: Elsevier, 1984.

24 Jack D, Poynter D, Smith RN. Antisecretory drugs and gastric cancer. $\mathrm{Br}$ Med J 1985; 291: 675.

25 Gad A. Intestinal metaplasia and gastric carcinoma. In: Si-Chun Ming, ed. Precursors of gastric cancer. New York: Praegar, 1984: 195-206.

26 Poynter D, Pick CR, Harcourt RA et al. Evaluation of ranitidine safety. In: Misiewicz $\mathrm{JJ}$, Wormsley $\mathrm{KG}$, eds. The clinical use of ranitidine. Oxford: Medicine Publishing Foundation, 1981.

27 Ganellin CR. The characterisation and development of cimetidine as a histamine $\mathrm{H}_{2}$ receptor antagonist. In: Harvengt $\mathrm{C}$ et al, eds. Proceedings of a national symposium on cimetidine. Oxford: Excerpta Medica, 1978: 1-13. 